\title{
Epidemiology of Plasmodium infections in Flores Island, Indonesia using real-time PCR
}

Maria MM Kaisar ${ }^{1,2}$, Taniawati Supali ${ }^{1}$, Aprilianto E Wiria ${ }^{1,2}$, Firdaus Hamid ${ }^{1,3}$, Linda J Wammes², Erliyani Sartono ${ }^{2}$, Adrian JF Luty ${ }^{4}$, Eric AT Brienen ${ }^{2}$, Maria Yazdanbakhsh², Lisette van Lieshout ${ }^{2 *}$ and Jaco J Verweij ${ }^{2,5}$

\begin{abstract}
Background: DNA-based diagnostic methods have been shown to be highly sensitive and specific for the detection of malaria. An 185-rRNA-based, real-time polymerase chain reaction (PCR) was used to determine the prevalence and intensity of Plasmodium infections on Flores Island, Indonesia.

Methods: Microscopy and real-time multiplex PCR for the detection of Plasmodium species was performed on blood samples collected in a population-based study in Nangapanda Flores Island, Indonesia.

Results: A total 1,509 blood samples were analysed. Real-time PCR revealed prevalence for Plasmodium falciparum, Plasmodium vivax, and Plasmodium malariae to be $14.5 \%, 13.2 \%$, and $1.9 \%$ respectively. Sub-microscopic parasitaemia were found in more than $80 \%$ of all positive cases. The prevalence of $P$. falciparum and $P$. vivax was significantly higher in subjects younger than 20 years $(p \leq 0.01)$. In the present study, among non-symptomatic healthy individuals, anaemia was strongly correlated with the prevalence and load of $P$. falciparum infections ( $p \leq 0.01 ; p=0.02$ ) and with the load of $P$. vivax infections $(p=0.01)$ as detected with real-time PCR. Subjects with $A B$ blood group tend to have a higher risk of being infected with $P$. falciparum and $P$. vivax when compared to other blood groups.

Conclusion: The present study has shown that real-time PCR provides more insight in the epidemiology of Plasmodium infections and can be used as a monitoring tool in the battle against malaria. The unsurpassed sensitivity of real-time PCR reveals that sub microscopic infections are common in this area, which are likely to play an important role in transmission and control.
\end{abstract}

Trial registration: Trials number ISRCTN83830814.

Keywords: Malaria, Plasmodium falciparum, Plasmodium vivax, Plasmodium malariae, Real-time PCR, Diagnosis, Flores

\section{Background}

In Indonesia, 1.25 to 2.5 million probable malaria cases with 45 to $50 \%$ being cases of Plasmodium falciparum, nearly 350,000 confirmed malaria cases, and around 500 confirmed malaria deaths, are reported every year [1]. Based on the Annual Parasite Incidence data the highest risk of acquiring malaria is in the eastern part of Indonesia. In 2008, a mass blood survey in more than 200,000 subjects performed by the Basic Health Research

\footnotetext{
* Correspondence: E.A.van_Lieshout@lumc.nl

${ }^{2}$ Department of Parasitology, Center of Infectious Diseases, Leiden University Medical Center, Albinusdreef 2, Leiden 2333 ZA, The Netherlands Full list of author information is available at the end of the article
}

Institute of East Nusa Tenggara showed 15\% of the blood slides to be positive for malaria parasites [2].

Although microscopic diagnosis of malaria is easy to perform, consumable costs are low, and it allows quantification and species identification [3,4], in many malaria-endemic areas microscopy of thin and thick smears of peripheral blood remains challenging. It is time consuming and needs well-trained and dedicated personnel, and even then misdiagnosis in cases of low parasitaemia and incorrect species identification occurs frequently [5-7].

Alternatively, DNA-based detection methods have been developed targeting different Plasmodium genes showing high sensitivity and specificity. The $18 \mathrm{~S}$ ribosomal RNA gene has been used successfully as a target for malaria

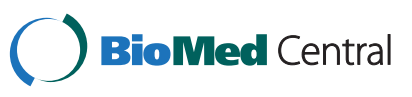


diagnosis in conventional polymerase chain reaction (PCR) and real-time PCR in several studies [8-11]. These assays allow sensitive far below the detection limit of microscopy and specific detection and differentiation of the different Plasmodium species [12-14]. Moreover, real-time PCR is not only able to provide information on parasite species but it also provides quantitative data on the parasite load.

In the present study, a multiplex real-time PCR was used to determine the epidemiological profile of Plasmodium infections in a malaria-endemic area in Flores, Indonesia.

\section{Methods}

This study was approved by the ethical committee from Faculty of Medicine, University of Indonesia in ref: 194/PT02.FK/ETIK/2006 and has been filed by ethical committee of the Leiden University Medical Centre. The present cross-sectional observational study is part of a larger study on co-infection between malaria and soil-transmitted helminths in Ende district [15], NTT which is listed in SPIN-KNAW projects [16].

\section{Study area}

Nangapanda village, Ende district, Flores Island, Indonesia (Figure 1) is a semi-urban village with an estimated population of 22,000 living in 18 sub villages. It is situated near the Equator, characterized by a high uniform temperature in range of 23 to $33.5^{\circ} \mathrm{C}$ and humidity is 86 to $95 \%$. Average yearly rainfall is $1.822 \mathrm{~mm}$ with around 82 rainy days, especially during November to April and the highest in December until March. The local Puskesmas (primary health centre) is responsible for providing health services to people living in the 18 sub villages. Based on the results of a preliminary survey in 2005-2006, three sub villages: Ndeturea (sub village 1), Ndorurea 1 (sub village 2) and Ndorurea (sub village 3 ) have a high prevalence of malaria cases as reported by the Puskesmas. These three sub villages were enrolled in this study. The purpose of the study was explained and informed consent was requested. Informed consent for children was obtained from their parents or guardians. The name, sex, age, and home address of each participant was recorded by the research team.

\section{Blood collection}

Venous blood samples were collected during dry season between June and August 2008 from participants above four years of age in Ndeturea, Ndorurea 1 and Ndorurea. Blood samples $(6 \mathrm{ml})$ were collected in tubes containing sodium heparin as anticoagulant. Eight microlitres and two microlitres from each sample was used to prepare a thick and thin blood smear, respectively; $200 \mu \mathrm{l}$ was stored at $-20^{\circ} \mathrm{C}$ for real-time $\mathrm{PCR}$ and the remainder was used to test a range of immunological markers as part of a larger study $[15,17]$. The samples were transported to the central laboratory in Jakarta and stored at $-80^{\circ} \mathrm{C}$.

\section{Blood parameters and temperature measurement}

Haemoglobin level was measured using a blood analyzer system (COULTER ${ }^{\odot}$ Ac-T diff $2^{\mathrm{rm}}$, Beckman Coulter, USA). Haemoglobin levels were divided into normal and anaemic according to criteria used by the Indonesian General Hospital, Cipto Mangunkusumo. The normal values for children (one month to six years), girls (seven to 13 years), boys (seven to 13 years), women ( $>13$ years) and men ( $>13$ years) are haemoglobin 11.5-15.5 g/dl, 12-16 g/dl, 13-16 g/dl, 12-14 g/dl, and 13-16 g/dl, respectively. Cases with haemoglobin levels below these normal values were categorized as anaemic.

The ABO blood typing was performed using monoclonal grouping kit (Fortress Diagnostics Ltd, UK).

The oral temperature was measured using a digital thermometer (General Care, China) and categorized in three groups: low, normal, and high (fever) for temperature level: $<36.1^{\circ} \mathrm{C}, 36.1-37.5^{\circ} \mathrm{C}$, and $>37.5^{\circ} \mathrm{C}$, respectively [18].

\section{Microscopic examination}

Duplo slides of both thin and thick smears for malaria diagnosis were made on the same day of blood collection and Giemsa-stained within 48 hours. The guidelines of the WHO Secretariat for the Coordination of Malaria Training in Asia and the Pacific were used as standard operating procedure. The slides were stored in slide boxes at room temperature. Thin and thick smears were examined using $1,000 \times$ oil immersion light microscopy for the presence of malaria parasites [19,20]. Microscopic examination of the slides was performed blinded by experienced technicians and approximately $10 \%$ of the slides were cross-checked randomly for quality control by a second experienced microscopist at the Department of Parasitology, Medical Faculty, University of Indonesia.

\section{DNA extraction}

Parasite DNA was isolated from $200 \mu \mathrm{l}$ blood using QIAamp DNA-easy 96-well plates according to the manufacturer's recommendations (Qiagen, Hilden, Germany). In each sample, $10^{3} \mathrm{PFU} / \mathrm{ml}$ phocin herpes virus-1 (PhHV-1) was added within the isolation lysis buffer to serve as an internal control [21]. DNA was stored at $4^{\circ} \mathrm{C}$.

\section{Real-time PCR}

Plasmodium-specific primers and P. falciparum, Plasmodium vivax, Plasmodium ovale and Plasmodium malariae-specific probes were used as described previously [15]. Amplification reactions were performed in white PCR plates, in a volume of $25 \mu \mathrm{l}$ with PCR buffer 


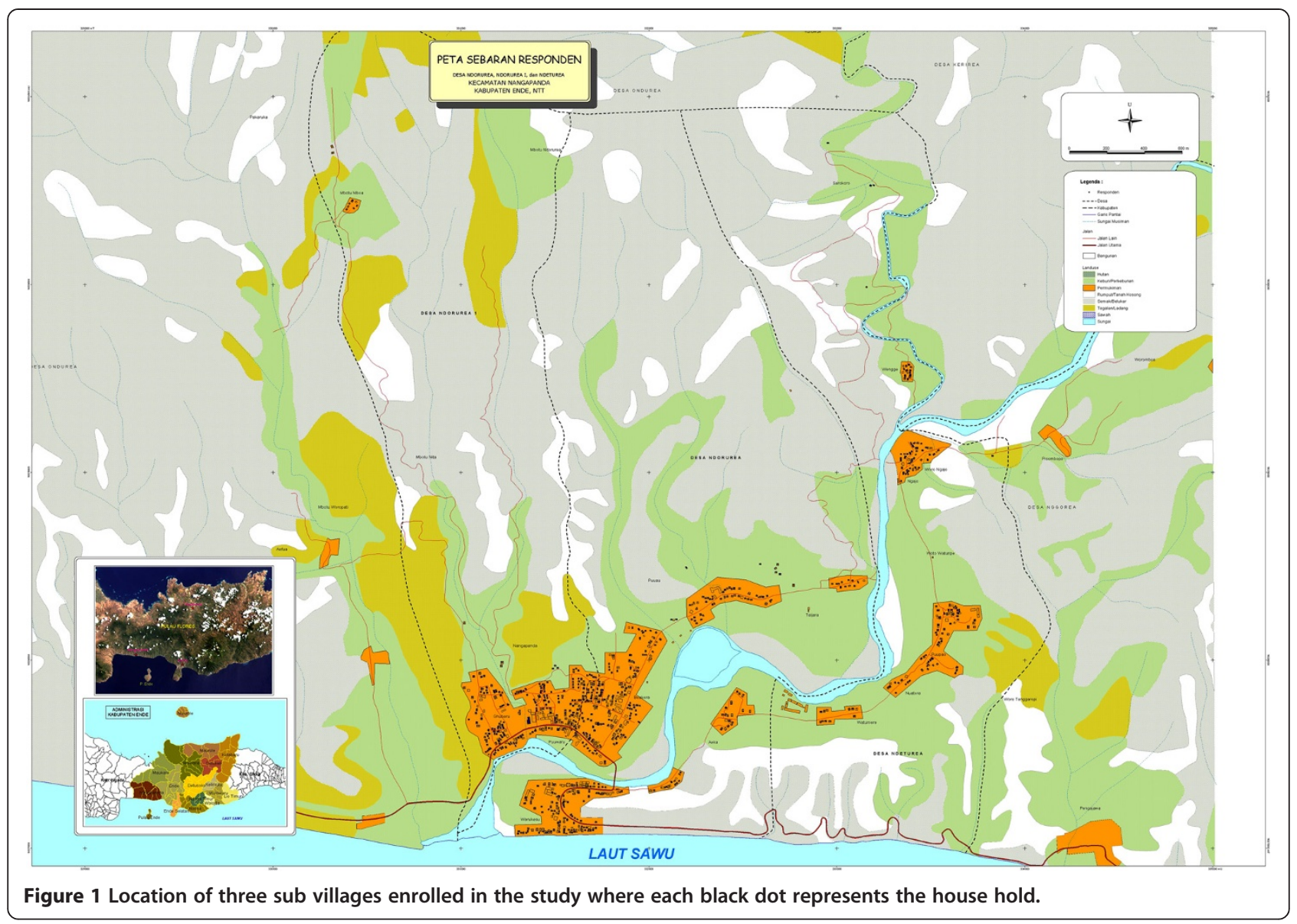

(HotstarTaq mastermix; Qiagen, Valencia, USA), a total of $5 \mathrm{mmol} / \mathrm{l} \mathrm{MgCl} 2,12.5 \mathrm{pmol}$ of each Plasmodiumspecific primer and 15 pmol of each PhHV-1-specific primer, $1.25 \mathrm{pmol}$ of each $P$. falciparum, $P$. vivax, $P$. malariae-specific XS-probes, and PhHV-1-specific Cy5 double-labelled detection probe, $2.5 \mathrm{pmol}$ of each $P$. ovale-specific XS-probes (Biolegio, Nijmegen, The Netherlands) and $5 \mu \mathrm{l}$ of DNA sample. Amplification comprised of $15 \mathrm{~min}$ at $95^{\circ} \mathrm{C}$, followed by 50 cycles of $15 \mathrm{sec}$ at $95^{\circ} \mathrm{C}, 30 \mathrm{sec}$ at $60^{\circ} \mathrm{C}$ and $30 \mathrm{sec}$ at $72^{\circ} \mathrm{C}$. Negative and positive control samples for each four species were included in each PCR run.

Amplification, detection, and analysis were performed using the CFX real-time detection system (Bio-Rad Laboratories, USA). The PCR output from this system consists of a cycle-threshold $(\mathrm{Ct})$ value, representing the amplification cycle in which the level of fluorescent signal exceeds the background fluorescence reflecting the parasite-specific DNA load in the sample tested. The amplification is considered to be hampered by inhibitory factors if the expected cycle threshold $(\mathrm{Ct})$ value in the PhHV-specific PCR was increased by more than 3.3 cycles.
Positive Ct- values were grouped into three groups: $\mathrm{Ct}<30.0, \quad 30.0<\mathrm{Ct}<35.0$ and $>35.0$ representing a high, moderate and low DNA load, respectively.

DNA isolation and set up of the PCR reactions were performed using a custom-made Hamilton robot platform.

\section{Data analysis}

All data were recorded on standardized case report forms using Excel spreadsheets, stored in an Access database (Microsoft, Redmond, USA) and exported for analysis in SPSS 17.0. Analysis for real-time PCR results was done using CFX Manager ${ }^{\mathrm{Tm}}$ Software Version 1.0, Bio-Rad. Chi-square distribution for the risk of being infected with a Plasmodium species, age, residence, gender and sub microscopic infection were calculated as a proportion of parasite infections detected in these groups. Continuous variables were described by the range and median of all PCR-positive cases and were compared between groups by the Mann Whitney-Non Parametric Test. Statistical significance was considered at p-value $<0.05$. 


\section{Results}

\section{Study population}

A total of 1,516 blood samples were available for microscopy and PCR. Seven samples were excluded due to failure of the DNA isolation or inhibition of the DNA amplification reaction. Figure 2 shows the flow chart of the samples in the study. The final number of samples included in the analysis was 1,509 with ages ranging from four to 79 years, mean and median age of 29 and 27 years, respectively. Participants older than 20 years were over-represented in the analysis group compared to the total population (57.9\% vs 42.1\%). The proportion of males in the analysis group (41.7\%) was slightly less than the proportion of males in population (45.3\%). A detailed comparison of the population and participants' characteristics is given in an additional table [see Additional file 1]. Participant characteristics per sub village are described in Additional file 2.

\section{Microscopy versus real-time PCR}

The results of microscopy and real-time PCR are summarized in Table 1. Fifty-two (3.4\%) of all available samples in the study were positive by microscopic examination and confirmed with real-time PCR. Plasmodium falciparum, $P$. vivax and $P$. malariae-specific DNA amplification was shown in a total of $399(26.4 \%)$ subjects.

Discrepancies between positive results in the microscopy and real-time PCR were observed in 14 cases. In seven

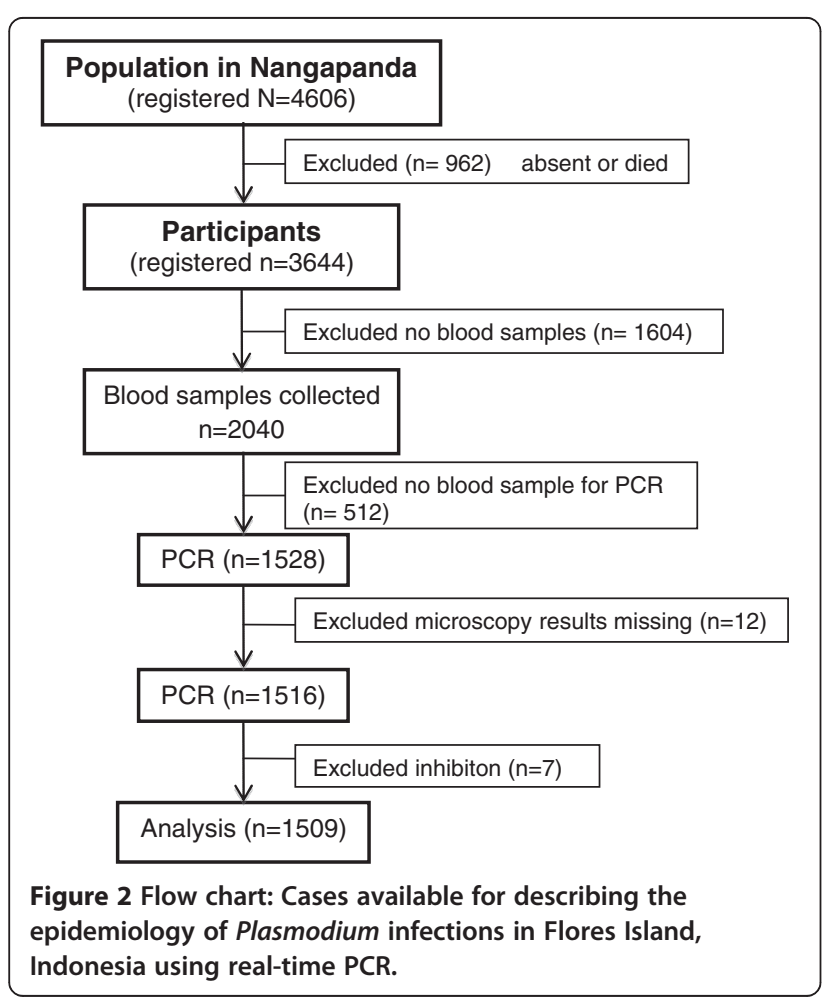

cases real-time PCR revealed another Plasmodium species than the species that was determined with microscopy. In another seven samples Plasmodium-specific DNA could not be detected, neither with the Plasmodium speciesspecific probes nor when checked for Plasmodium genusspecific amplification using agarose gel-electrophoreses.

Plasmodium falciparum, $P$. vivax and $P$. malariae parasites were detected with PCR only (i e, were sub microscopic) in $83.1 \%, 94.5 \%$ and $82.1 \%$ of the subjects, respectively. Median Ct-values of $P$. falciparum, $P$. vivax and $P$. malariae-specific amplification in sub microscopic cases were higher (i e, lower DNA load) compared to the median Ct-values of microscopy positive subjects 35.3, 36.3 and 36.4 versus $30.4,28.7$ and 30.8 , respectively ( $\mathrm{p}$ values $\leq 0.02$ ).

\section{Epidemiology of Plasmodium infections using real-time PCR}

Plasmodium falciparum, $P$. vivax and P. malariaespecific DNA amplification was shown in $14.5 \%, 13.2 \%$ and $1.9 \%$ of the samples, respectively. The distribution of Plasmodium species and infections in each sub village is summarized in Table 1 . In all three sub-villages, $P$. falciparum, $P$. vivax and $P$. malariae, and subjects with mixed infections were detected. Mixed infections of $P$. falciparum and $P$. vivax were detected in 41 subjects and in six subjects a mixed infection of $P$. falciparum and P. malariae was found. The highest prevalence of Plasmodium infections was detected in Ndeturea (30.9\%) compared by Ndoturea 1 (24.9\%), and Ndorurea (25.5\%), but the difference was not statistically significant.

Figure 3 shows the parasite-specific DNA loads of $P$. falciparum and P. vivax in the different age groups. A high load of Plasmodium species-specific DNA (Ct $<30)$ was found for P. falciparum, $P$. vivax and P. malariae in $10.5 \%, 4 \%$ and $14.3 \%$ of the positive cases, respectively. A moderate DNA load (Ct 30-35) was found for $P$. falciparum (43.8\%), P. vivax (31\%), and P. malariae (39.3\%) and a low DNA load $(\mathrm{Ct}>35)$ was detected for $P$. falciparum (45.7\%), P. vivax (65\%) and P. malariae (46.4\%). Plasmodium malariae was not detected in subjects below five years of age.

\section{Factors associated with Plasmodium infection}

Table 2 summarizes the Plasmodium species-specific real-time PCR results in correlation with age, gender, haematological parameters, and body temperature. The prevalence of $P$. falciparum in subjects younger than 20 years $(22.4 \%)$ was significantly higher compared to the prevalence found in subjects older than 20 years $(8.7 \%)(\mathrm{p} \leq 0.001)$. The same was found for the prevalence of $P$. vivax in the young and older age group, $18.4 \%$ and $9.3 \%$, respectively $(\mathrm{p} \leq 0.001)$. The median $\mathrm{Ct}$-values of 
Table 1 Number of Plasmodium infections detected with microscopy and real-time PCR

\begin{tabular}{|c|c|c|c|c|c|}
\hline \multirow[t]{2}{*}{ Species } & \multirow{2}{*}{$\begin{array}{c}\text { Microscopy* } \\
\text { Total }\end{array}$} & \multicolumn{4}{|c|}{ Real-time PCR } \\
\hline & & Total & Ndeturea & Ndorurea 1 & Ndorurea \\
\hline P. falciparum & 36 & 172 & 51 & 52 & 69 \\
\hline P. vivax & 10 & 158 & 29 & 63 & 66 \\
\hline P. malariae & 5 & 22 & 11 & 3 & 8 \\
\hline Mixed Pf and Pv & 1 & 41 & 3 & 14 & 24 \\
\hline Mixed Pf and Pm & 0 & 6 & 5 & 1 & 0 \\
\hline Negative & 1457 & 1110 & 221 & 401 & 488 \\
\hline Total & 1509 & 1509 & 320 & 534 & 655 \\
\hline Total Prevalence & $3.4 \%$ & $26.4 \%$ & $30.9 \%{ }^{\#}$ & $24.9 \%{ }^{\#}$ & $25.5 \%{ }^{\#}$ \\
\hline
\end{tabular}

*confirmed by real-time PCR.

\#not significantly different $(p=0.118)$.

the P. falciparum PCR in subjects below 20 years were lower compared to subjects of 20 years and older, 34.2 and 36.0 respectively $(\mathrm{p}=0.003)$. The median $\mathrm{Ct}$-values in the $P$. vivax PCR were not significantly different in the young and older age group. Both prevalence and median
Ct-values of the $P$. malariae PCR in subjects below 20 years were not significantly different compared to the subjects older than 20 years.

The prevalence of Plasmodium infections in males compared to females was significantly different for $P$. vivax

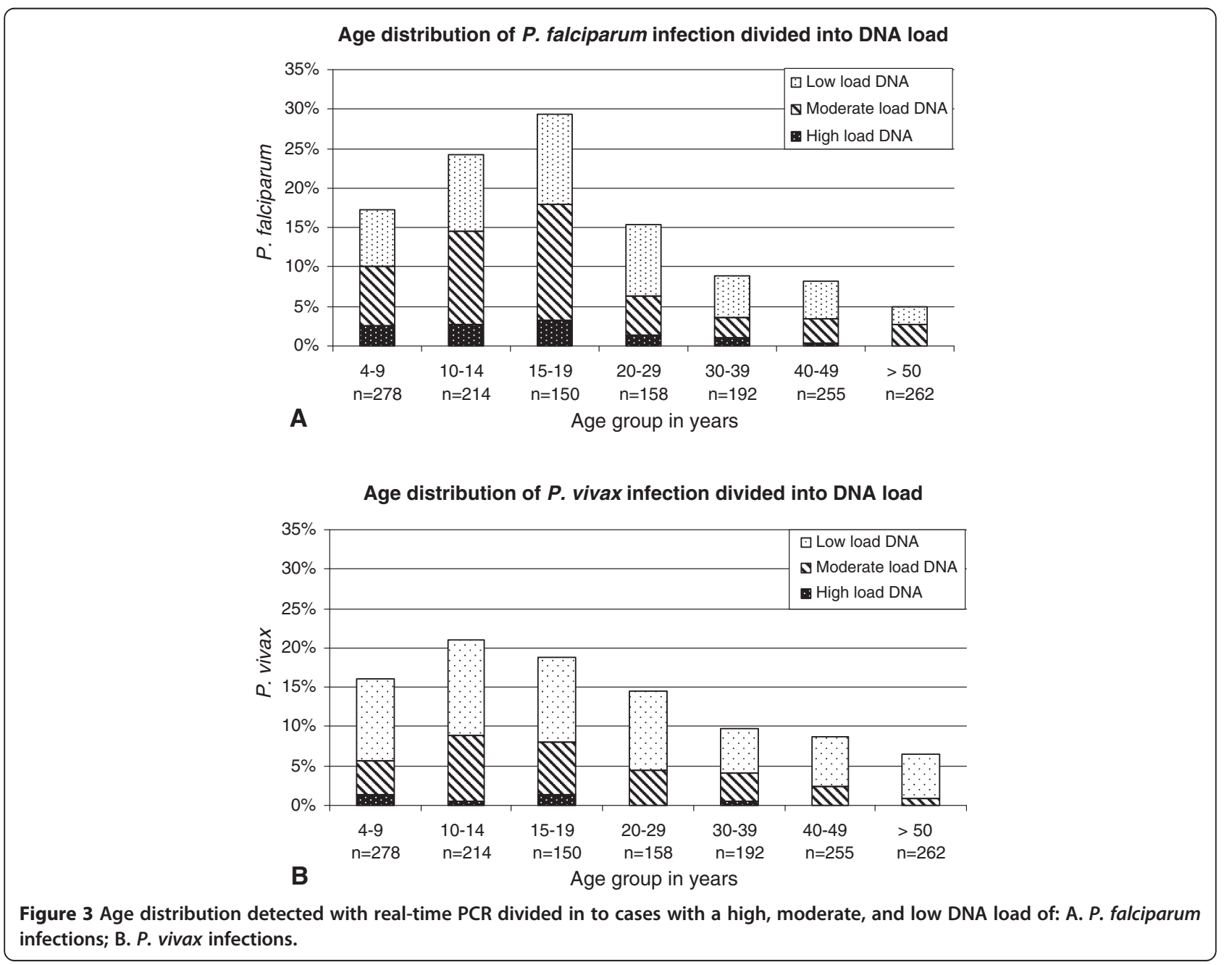


Table 2 Plasmodium species-specific real-time PCR results in correlation with age, gender, body temperature, haemoglobin levels, and $\mathrm{ABO}$ blood group typing results

\begin{tabular}{|c|c|c|c|c|c|c|c|c|}
\hline \multicolumn{3}{|l|}{ Variables } & \multirow{2}{*}{$\begin{array}{c}\text { n total } \\
642\end{array}$} & \multirow{2}{*}{$\begin{array}{c}\text { \% Positive } \\
22.4\end{array}$} & \multirow{2}{*}{$\begin{array}{c}\text { p-value }^{1} \\
<0.001\end{array}$} & \multirow{2}{*}{$\frac{\text { Ct-value median }}{34.2}$} & \multirow{2}{*}{$\begin{array}{c}\text { Ct-value range } \\
24.2-48.7\end{array}$} & \multirow{2}{*}{$\frac{p \text {-value }}{2}$} \\
\hline Age group (years) & $\mathrm{Pf}$ & $<20$ & & & & & & \\
\hline & & $\geq 20$ & 867 & 8.7 & & 36.0 & $28.3-43.5$ & \\
\hline & $\mathrm{PV}$ & $<20$ & 642 & 18.4 & $<0.001$ & 35.7 & $26.5-48.3$ & n.s. \\
\hline & & $\geq 20$ & 867 & 9.3 & & 36.5 & $28.3-46.1$ & \\
\hline & $\mathrm{Pm}$ & $<20$ & 642 & 2.0 & n.s. & 33.0 & $27.2-43.7$ & n.s. \\
\hline & & $\geq 20$ & 867 & 1.7 & & 36.0 & $29.8-41.0$ & \\
\hline \multirow[t]{6}{*}{ Gender } & Pf & Male & 629 & 15.9 & n.s. & 34.0 & $24.2-46.0$ & n.s. \\
\hline & & Female & 880 & 13.5 & & 34.9 & $27.2-48.7$ & \\
\hline & $\mathrm{PV}$ & Male & 629 & 15.7 & 0.013 & 36.0 & $28.3-43.2$ & n.s. \\
\hline & & Female & 880 & 11.4 & & 36.1 & $26.5-48.3$ & \\
\hline & $\mathrm{Pm}$ & Male & 629 & 1.9 & n.s. & 36.6 & $28.8-43.7$ & n.s. \\
\hline & & Female & 880 & 1.8 & & 32.1 & $27.2-42.7$ & \\
\hline \multirow[t]{6}{*}{ Haemoglobin } & Pf & Normal & 400 & 12.8 & $<0.001$ & 34.9 & $27.1-43.5$ & 0.02 \\
\hline & & Anaemia & 138 & 30.4 & & 32.7 & $25.1-42.0$ & \\
\hline & $\mathrm{PV}$ & Normal & 400 & 12.5 & n.s. & 36.9 & $28.3-48.3$ & 0.01 \\
\hline & & Anaemia & 138 & 15.9 & & 34.2 & $26.5-41.6$ & \\
\hline & $\mathrm{Pm}$ & Normal & 400 & 2.0 & n.s. & 36.3 & 28.8-38.1 & n.s. \\
\hline & & Anaemia & 138 & 2.9 & & 32.1 & $30.7-40.7$ & \\
\hline \multirow[t]{16}{*}{ Blood Group } & Pf & A & 320 & 12.5 & & 35.3 & $25.1-42.6$ & \\
\hline & & B & 315 & 13.0 & & 34.1 & $25.9-43.4$ & \\
\hline & & O & 564 & 13.1 & n.s. ${ }^{\#}$ & 34.3 & $24.2-78.7$ & n.s. ${ }^{\#}$ \\
\hline & & $A B$ & 64 & 18.8 & & 37.2 & $29.3-38.8$ & \\
\hline & $\mathrm{PV}$ & A & 320 & 10.3 & & 36.2 & $28.3-46.1$ & \\
\hline & & B & 315 & 15.9 & & 36.3 & $31.1-43.2$ & \\
\hline & & O & 564 & 12.4 & n.s. ${ }^{\#}$ & 36.3 & $27.7-44.2$ & n.s. ${ }^{\#}$ \\
\hline & & $A B$ & 64 & 20.3 & & 35.8 & 28.7-39.0 & \\
\hline & $\mathrm{Pm}$ & $A$ & 320 & 1.9 & & 35.1 & $27.2-41.0$ & \\
\hline & & B & 315 & 1.6 & & 36.0 & $28.0-36.7$ & \\
\hline & & 0 & 564 & 2.0 & n.s." & 34.8 & $30.7-43.7$ & n.s. ${ }^{\#}$ \\
\hline & & $A B$ & 64 & 1.6 & & 0 & 40.7 & \\
\hline & Pf & $<36.5$ & 394 & 12.4 & & 34.3 & $24.2-48.7$ & \\
\hline & & $36.5-37.5$ & 1094 & 14.9 & & 34.5 & $25.1-46.0$ & n.s. \\
\hline & & $>37.5$ & 8 & 50.0 & & 34.1 & $31.5-39.4$ & \\
\hline & Pv & $<36.5$ & 394 & 14.2 & & 36.2 & $28.3-48.3$ & \\
\hline Temperature & & $36.5-37.5$ & 1094 & 12.7 & & 36.0 & $26.5-46.1$ & n.s. \\
\hline \multirow[t]{4}{*}{$\left({ }^{\circ} \mathrm{C}\right)$} & & $>37.5$ & 8 & 12.5 & & 40.5 & 40.5 & \\
\hline & $\mathrm{Pm}$ & $<36.5$ & 394 & 2.0 & & 31.4 & $27.9-36.8$ & \\
\hline & & $36.5-37.5$ & 1094 & 1.8 & & 35.4 & $27.2-43.7$ & n.s. \\
\hline & & $>37.5$ & 8 & 0.0 & & - & - & \\
\hline
\end{tabular}

\footnotetext{
${ }^{1}$ Pearson Chi square test.

${ }^{2}$ Non Parametric Test (NPT) with Mann Whitney.

\# $p$-value of blood group $A B$ compared to non $A B$ blood group.

n.s. Not Significant.
} 
$15.7 \%$ versus $11.4 \%$, respectively $(\mathrm{p}=0.01)$. There was no difference in prevalence of $P$. falciparum and $P$. malariae. The median Ct-values of $P$. falciparum, $P$. vivax and $P$. malariae-specific amplification in males were not significantly different compared to those in females.

The haemoglobin concentration was measured in 538 of 1,509 of the participants. Normal haemoglobin level was found in $74.3 \%$ of the subjects and $25.7 \%$ were categorized as anaemic. The number of $P$. falciparum-positive subjects was significantly higher $(\mathrm{p} \leq 0.001)$ in anaemic participants as compared to the subjects with a normal haemoglobin level. There was no difference in the number of $P$. vivax and $P$. malariae positive subjects in the anaemic and non-anaemic group. The median Ct-values of $P$. falciparum and $P$. vivax -specific amplification were lower in the anaemic cases compared to the non-anaemic subjects ( $\mathrm{p}=0.02$ and $\mathrm{p}=0.01$ respectively).

Blood grouping was performed in 1,263 of 1,509 subjects. Blood group $\mathrm{A}, \mathrm{B}, \mathrm{AB}$, and $\mathrm{O}$ was found in $25.3 \%, 24.9 \%$, $5.1 \%$ and $44.7 \%$ of the subjects, respectively. The highest prevalence of Plasmodium infections was found in subjects with blood group $\mathrm{AB}$ as compared to the other blood groups. The prevalence and median $\mathrm{Ct}$-values of all three Plasmodium species separately were not different between the subjects with different blood groups.

Body temperature was recorded in 1,496 of 1,509 participants. A low body temperature $\left(<36.1^{\circ} \mathrm{C}\right)$ was found in $26.3 \%$ of the participants, a normal body temperature $\left(36.1-37.5^{\circ} \mathrm{C}\right)$ in $73.1 \%$ and eight of 1,509 $(0.5 \%)$ showed a high body temperature $\left(>37.5^{\circ} \mathrm{C}\right)$. There was no difference in the number of Plasmodium infections in the cases with a low and normal body temperature. Plasmodium falciparum was detected in four of eight subjects with a high body temperature. However, the number of subjects in this group was too small for statistical analysis.

\section{Discussion}

In the present population-based study on Flores Island, Indonesia, $P$. falciparum, $P$. vivax, $P$. malariae and mixed infections were detected with PCR in $11.4 \%, 10.5 \%, 1.5 \%$, and $3.1 \%$ of the participants, respectively. Only $87 \%$ of all infections were revealed using real-time PCR. The higher sensitivity of the real-time PCR is reflected in the lower DNA load in microscopy-negative subjects compared to the DNA load found in microscopy-positive subjects.

Plasmodium falciparum prevalence increased up to 15-19 years of age and decreased in the older age groups; also the parasite load was significantly higher in the participants under 20 years whereas the prevalence of $P$. vivax started to decrease somewhat earlier in age. In areas with higher transmission intensity, such as Irian Jaya and in Africa, the peak in prevalence and parasitaemia is usually observed at a younger age due to an earlier acquired immunity [22-24].

Although only significant for $P$. vivax, the numbers of malaria infections were found higher in males than females. This could be more due to working outdoors in the field resulting in a higher exposure to mosquito bites, but then higher $P$. falciparum and $P$. malariae infections would be expected. This was also shown in a study performed in India [25] but in contrast with a study in Popondeta, Papua New Guinea, located close to the eastern part of Indonesia, where no significant difference was found in malaria prevalence between males and females [26]. A more detailed statistical analysis of links between gender, work, local ecological, environmental, economic and cultural factors, which might influence exposure to risk of infection and the disease, has been planned for the future.

Clearly anaemia is a well-known phenomenon associated with malaria disease, but also in the present study among apparently healthy individuals, anaemia was strongly correlated with the prevalence and load of $P$. falciparum infections, which is in agreement with other studies in asymptomatic subjects [27-32]. In the present study, anaemia was also correlated with the load of $P$. vivax infections. Although anaemia is a known complication in cases with severe $P$. vivax malaria, it is less known in latent $P$. vivax cases and might be underestimated due to misdiagnosis. Obviously anaemia is a multifactorial clinical phenomenon [33] and no correction was performed for potential other causes.

Several studies were performed to understand the contribution of $\mathrm{ABO}$ blood group antigens in protection against Plasmodium infections. Although meta-analysis has shown that blood group $\mathrm{O}$ provides selective advantages against severe malaria, other studies were unable to link ABO blood groups to the incidence of malaria [34-37]. In the present cross-sectional study, the prevalence of $P$. falciparum and $P$. vivax was higher, although not significantly in subjects with blood group $\mathrm{AB}$ compared to subjects with the other blood groups. This seems in contrast with previous findings; however, in the present study mostly sub microscopic Plasmodium infections were found using real-time PCR whereas previous studies used microscopy to detect malaria parasites. Further studies in areas of different endemicity using Plasmodium PCR will be needed to elucidate the role of $\mathrm{ABO}$ blood groups in acquiring infection and the outcome of disease in malaria.

The real-time PCR procedure as described in this paper is not suitable to use as a point of-care (POC) test in "treatment on diagnosis" control strategies. The high-throughput, however makes it very appealing to transport samples to a central laboratory for monitoring the effect of mass drug administration programs [38]. Moreover, nucleic acid based POC assays are in 
development as well, such as LAMP (loop-mediated isothermal amplification), nucleic acid amplification protocols directly from blood without DNA extraction, and lateral flow detection of PCR products [39-42].

In the present study real-time PCR has proved to be a powerful diagnostic tool providing novel insights into the epidemiology of malaria infections in a low transmission area. The high number of sub microscopic infections have important implications in the transmission dynamics [43-48] and have to be considered in novel elimination strategies [38,49-51]. Moreover, these low density malaria infections appear to play a role in eliciting or maintaining humoral immune responses $[48,52,53]$ and therefore should be taken into account in, for example studies on the immunology in malaria infections and the association with the regulatory responses that may be caused by chronic worm infections interacting with inflammation [15].

\section{Conclusions}

Real-time PCR revealed 7.8 times more Plasmodium infection compared to microscopy. Sub microscopic infections are common in this area, over $22 \%$ of the subjects in the study show sub microscopic Plasmodium infections, which might play an important role in transmission. Real-time PCR provides more insight into the epidemiology of Plasmodium infections, which could be applied for preventing, monitoring, and evaluation of novel programs for the elimination of malaria.

\section{Additional files}

Additional file 1: Comparison of age, gender, and residential area of the total population and participants.

Additional file 2: Age distribution and gender of participants from three sub villages in Nangapanda, Ende district.

\section{Competing interests}

The authors declare that they have no competing interests.

\section{Authors' contributions}

MY developed the study and is the Dutch coordinator of the ImmunoSPIN program. TS developed the study and is the Indonesian coordinator of the ImmunoSPIN program. ES contributed to the study coordination and advised on data collection. AEW, FH, and LJW contributed to setting up the field study, recruitment, and follow up and data collection. AJFL contributed to advice on manuscript. LVL and JJV led the work on real-time PCR detection of parasites. MMMK contributed to fieldwork, data collection, performed realtime PCR work. JJV and EATB helped to interpret the results of molecular diagnostic. MMMK and JJV contributed to the statistical analysis of the results and drafted manuscript. All authors read and approved the final manuscript.

\section{Acknowledgements}

This study was funded by the KNAW, and the Prof Dr P. F. C. Flu-Foundation. We thank the Directorate General of Higher Education (DGHE) of Indonesia, Leiden University Medical Center, and the Medical Faculty of the University of Indonesia as home base of education that supports the study. We are grateful to all participating villagers from Nangapanda for their excellent help and cooperation.

\section{Author details}

'Department of Parasitology, Faculty of Medicine, University of Indonesia, Jakarta, Indonesia. '2Department of Parasitology, Center of Infectious Diseases, Leiden University Medical Center, Albinusdreef 2, Leiden 2333 ZA, The Netherlands. ${ }^{3}$ Department of Microbiology, Faculty of Medicine, University of Hasanuddin, Makassar, Indonesia. ${ }^{4}$ Unités Mixtes de Recherche, Institut de Recherche pour le Développement, Mère et Enfant Face aux Infections, Tropicales, France. ${ }^{5}$ Current address: Laboratory for Medical Microbiology and Immunology, St. Elisabeth Hospital, Tilburg, The Netherlands.

Received: 29 January 2013 Accepted: 16 May 2013

Published: 24 May 2013

\section{References}

1. WHO SEARO 2011: Malaria situation in SEAR Countries: Indonesia; 2011 [http://www.searo.who.int?EN?Section10?Section21?Section340_4022.htm].

2. Depkes 2011: Epidemiologi Malaria. [http://www.depkes.go.id/index.php/ component/content/article/811.html]

3. Kain KC, Harrington MA, Tennyson S, Keystone JS: Imported malaria: prospective analysis of problems in diagnosis and management. Clin Infect Dis 1998, 27:142-149.

4. Moody A: Rapid diagnostic tests for malaria parasites. Clin Microbio/ Rev 2002, 15:66-78.

5. Amexo M, Tolhurst R, Barnish G, Bates I: Malaria misdiagnosis: effects on the poor and vulnerable. Lancet 2004, 364:1896-1898.

6. Hänscheid T, Melo-Cristino J, Grobusch MP, Pinto BG: Avoiding misdiagnosis of imported malaria: screening of emergency department samples with thrombocytopenia detects clinically unsuspected cases. J Travel Med 2003, 10:155-159.

7. Reyburn H, Mbatia R, Drakeley C, Carneiro I, Mwakasungula E, Mwerinde O, Saganda K, Shao J, Kitua A, Olomi R, Greenwood BM, Whitty CJ: Overdiagnosis of malaria in patients with severe febrile illness in Tanzania: a prospective study. BMJ 2004, 329:1212.

8. Adegnika AA, Verweij JJ, Agnandji ST, Chai SK, Breitling LP, Ramharter M, Frolich M, Issifou S, Kremsner PG, Yazdanbakhsh M: Microscopic and sub-microscopic Plasmodium falciparum infection, but not inflammation caused by infection, is associated with low birth weight. Am J Trop Med Hyg 2006, 75:798-803.

9. Mangold KA, Manson RU, Koay ES, Stephens L, Regner M, Thomson RB Jr, Peterson LR, Kaul KL: Real-time PCR for detection and identification of Plasmodium spp. J Clin Microbiol 2005, 43:2435-2440.

10. Muller-Stover I, Verweij JJ, Hoppenheit B, Gobels K, Haussinger D, Richter J: Plasmodium malariae infection in spite of previous anti-malarial medication. Parasitol Res 2008, 102:547-550.

11. Snounou G, Viriyakosol S, Jarra W, Thaithong S, Brown KN: Identification of the four human malaria parasite species in field samples by the polymerase chain reaction and detection of a high prevalence of mixed infections. Mol Biochem Parasitol 1993, 58:283-292.

12. Calderaro A, Piccolo G, Perandin F, Gorrini C, Peruzzi S, Zuelli C, Ricci L, Manca N, Dettori G, Chezzi C, Snounou G: Genetic polymorphisms influence Plasmodium ovale PCR detection accuracy. J Clin Microbio/ 2007, 45:1624-1627

13. Liu Q, Zhu S, Mizuno S, Kimura M, Liu P, Isomura S, Wang X, Kawamoto F: Sequence variation in the small-subunit rRNA gene of Plasmodium malariae and prevalence of isolates with the variant sequence in Sichuan, China. J Clin Microbiol 1998, 36:3378-3381.

14. Oddoux O, Debourgogne A, Kantele A, Kocken CH, Jokiranta TS, Vedy S, Puyhady JM, Machouart M: Identification of the five human Plasmodium species including $P$. knowlesi by real-time polymerase chain reaction. Eur J Clin Microbiol Infect Dis 2011, 30:597-601.

15. Wiria AE, Prasetyani MA, Hamid F, Wammes LJ, Lell B, Ariawan I, Uh HW, Wibowo H, Djuardi Y, Wahyuni S, Sutanto I, May L, Luty AJ, Verweij JJ, Sartono E, Yazdanbakhsh M, Supali T: Does treatment of intestinal helminth infections influence malaria? Background and methodology of a longitudinal study of clinical, parasitological and immunological parameters in Nangapanda, Flores, Indonesia (ImmunoSPIN Study). BMC Infect Dis 2010, 10:77.

16. SPIN-KNAW: 10 years SPIN: Looking ahead, looking back. [http://www. immunospin.org]

17. Hamid F, Wiria AE, Wammes LJ, Kaisar MM, Lell B, Ariawan I, Uh HW, Wibowo H, Djuardi Y, Wahyuni S, Schot R, Verweij JJ, van Ree R, May L, 
Sartono E, Yazdanbakhsh M, Supali T: A longitudinal study of allergy and intestinal helminth infections in semi urban and rural areas of Flores, Indonesia (ImmunoSPIN Study). BMC Infect Dis 2011, 11:83.

18. Mackowiak PA, Wasserman SS, Levine MM: An analysis of the quantitative relationship between oral temperature and severity of illness in experimental shigellosis. J Infect Dis 1992, 166:1181-1184.

19. Trape JF: Rapid evaluation of malaria parasite density and standardization of thick smear examination for epidemiological investigations. Trans R Soc Trop Med Hyg 1985, 79:181-184.

20. Petithory JC, Ardoin F, Ash LR: Rapid and inexpensive method of diluting Giemsa stain for diagnosis of malaria and other infestations by blood parasites. J Clin Microbiol 2005, 43:528.

21. Niesters HG: Clinical virology in real time. J Clin Virol 2002, 25(Suppl 3):S3-S12.

22. Baird JK, Purnomo Basri H, Bangs MJ, Andersen EM, Jones TR, Masbar S, Harjosuwarno S, Subianto B, Arbani PR: Age-specific prevalence of Plasmodium falciparum among six populations with limited histories of exposure to endemic malaria. Am J Trop Med Hyg 1993, 49:707-719.

23. Trape JF, Rogier C: Combating malaria morbidity and mortality by reducing transmission. Parasitol Today 1996, 12:236-240.

24. Snow RW, Marsh K: New insights into the epidemiology of malaria relevant for disease control. Br Med Bull 1998, 54:293-309.

25. Kumar A, Valecha N, Jain T, Dash AP: Burden of malaria in India: retrospective and prospective view. Am J Trop Med Hyg 2007, 77:69-78.

26. Pluess B, Mueller I, Levi D, King G, Smith TA, Lengeler C: Malaria-a major health problem within an oil palm plantation around Popondetta, Papua New Guinea. Malar J 2009, 8:56.

27. Igbeneghu $\mathrm{C}$, Odaibo $\mathrm{AB}$, Olaleye $\mathrm{DO}$ : Impact of asymptomatic malaria on some hematological parameters in the Iwo community in Southwestern Nigeria. Med Princ Pract 2011, 20:459-463.

28. Chang KH, Stevenson MM: Malarial anaemia: mechanisms and implications of insufficient erythropoiesis during blood-stage malaria. Int J Parasitol 2004, 34:1501-1516.

29. Coura JR, Suarez-Mutis M, Ladeia-Andrade S: A new challenge for malaria control in Brazil: asymptomatic Plasmodium infection-a review. Mem Inst Oswaldo Cruz 2006, 101:229-237.

30. Lamikanra AA, Brown D, Potocnik A, Casals-Pascual C, Langhorne J, Roberts DJ: Malarial anemia: of mice and men. Blood 2007, 110:18-28.

31. Syafruddin D, Krisin Asih P, Sekartuti Dewi RM, Coutrier F, Rozy IE, Susanti Al, Elyazar IR, Sutamihardja A, Rahmat A, Kinzer M, Rogers WO: Seasonal prevalence of malaria in West Sumba district, Indonesia. Malar J 2009, 8:8.

32. Haldar K, Mohandas N: Malaria, erythrocytic infection, and anemia. Hematol Am Soc Hematol Educ Program 2009, 1:87-93.

33. Calis JC, Phiri KS, Faragher EB, Brabin BJ, Bates I, Cuevas LE, de Haan RJ, Phiri Al, Malange P, Khoka M, Hulshof PJ, van Lieshout L, Beld MG, Teo YY, Rockett KA, Richardson A, Kwiatkowski DP, Molyneux ME, van Hensbroek MB: Severe anemia in Malawian children. N Engl J Med 2008, 358:888-899.

34. Uneke CJ, Sunday-Adeoye I, Iyare FE, Ugwuja El, Duhlinska DD: Impact of maternal Plasmodium falciparum malaria and haematological parameters on pregnancy and its outcome in southeastern Nigeria. $J$ Vector Borne Dis 2007, 44:285-290.

35. Rowe JA, Opi DH, Williams TN: Blood groups and malaria: fresh insights into pathogenesis and identification of targets for intervention. Curr Opin Hematol 2009, 16:480-487.

36. Deepa Alwar VA, Rameshkumar K, Ross C: ABO blood groups and malaria related clinical outcome. J Vector Borne Dis 2011, 48:7-11.

37. Anstee DJ: The relationship between blood groups and disease. Blood 2010, 115:4635-4643.

38. World Health Organization: Consideration of mass drug administration for the containment of artemisinin resistant malaria in the greater Mekong subregion, WHO report of a consensus meeting. Geneva: WHO; 2011.

39. Abdul-Ghani R, Al-Mekhlafi AM, Karanis P: Loop-mediated isothermal amplification (LAMP) for malarial parasites of humans: would it come to clinical reality as a point-of-care test? Acta Trop 2012, 122:233-240.

40. Cordray MS, Richards-Kortum RR: Emerging nucleic acid-based tests for point-of-care detection of malaria. Am J Trop Med Hyg 2012, 87:223-230.

41. Han ET: Loop-mediated isothermal amplification test for the molecular diagnosis of malaria. Expert Rev Mol Diagn 2013, 13:205-218.

42. Mens PF, de Bes HM, Sondo P, Laochan N, Keereecharoen L, van Amerongen A, Flint J, Sak JR, Proux S, Tinto H, Schalling HD: Direct blood $\mathrm{PCR}$ in combination with nucleic acid lateral flow immunoassay for detection of Plasmodium species in settings where malaria is endemic. J Clin Microbiol 2012, 50:3520-3525.

43. Okell LC, Ghani AC, Lyons E, Drakeley CJ: Submicroscopic infection in Plasmodium falciparum-endemic populations: a systematic review and meta-analysis. J Infect Dis 2009, 200:1509-1517.

44. Harris I, Sharrock WW, Bain LM, Gray KA, Bobogare A, Boaz L, Lilley K, Krause D, Vallely A, Johnson ML, Gatton ML, Shanks GD, Cheng Q: A large proportion of asymptomatic Plasmodium infections with low and sub-microscopic parasite densities in the low transmission setting of Temotu Province. Solomon Islands: challenges for malaria diagnostics in an elimination setting. Malar J 2010, 9:254.

45. Bousema T, Drakeley C: Epidemiology and infectivity of Plasmodium falciparum and Plasmodium vivax gametocytes in relation to malaria control and elimination. Clin Microbiol Rev 2011, 24:377-410.

46. Manjurano A, Okell L, Lukindo T, Reyburn H, Olomi R, Roper C, Clark TG, Joseph S, Riley EM, Drakeley C: Association of sub-microscopic malaria parasite carriage with transmission intensity in north-eastern Tanzania. Malar J 2011, 10:370

47. Karl S, Gurarie D, Zimmerman PA, King CH, St Pierre TG, Davis TM: A sub-microscopic gametocyte reservoir can sustain malaria transmission. PLoS One 2011, 6:e20805

48. Okell LC, Bousema T, Griffin JT, Ouedraogo AL, Ghani AC, Drakeley CJ: Factors determining the occurrence of submicroscopic malaria infections and their relevance for control. Nat Commun 2012, 3:1237.

49. Shekalaghe S, Drakeley C, Gosling R, Ndaro A, van Meegeren M, Enevold A Alifrangis M, Mosha F, Sauerwein R, Bousema T: Primaquine clears submicroscopic Plasmodium falciparum gametocytes that persist after treatment with sulphadoxine-pyrimethamine and artesunate. PLOS One 2007, 2:e1023

50. Baird JK: Primaquine toxicity forestalls effective therapeutic management of the endemic malarias. Int J Parasitol 2012, 42:1049-1054.

51. Baird JK: Chemotherapeutic challenges in developing effective treatments for the endemic malarias. Int J Parasitol 2012, 2:256-261.

52. Shekalaghe S, Alifrangis M, Mwanziva C, Enevold A, Mwakalinga S, Mkali H, Kavishe R, Manjurano A, Sauerwein R, Drakeley C, Bousema T: Low density parasitaemia, red blood cell polymorphisms and Plasmodium falciparum specific immune responses in a low endemic area in northern Tanzania. BMC Infect Dis 2009, 9:69.

53. Proietti C, Verra F, Bretscher MT, Stone W, Kanoi BN, Balikagala B, Egwang TG, Corran P, Ronca R, Arcà B, Riley EM, Crisanti A, Drakeley C, Bousema T: Influence of infection on malaria-specific antibody dynamics in a cohort exposed to intense malaria transmission in northern Uganda. Parasite Immunol 2013, 35:164-173.

doi:10.1186/1475-2875-12-169

Cite this article as: Kaisar et al:: Epidemiology of Plasmodium infections in Flores Island, Indonesia using real-time PCR. Malaria Journal 2013 $12: 169$

\section{Submit your next manuscript to BioMed Central and take full advantage of:}

- Convenient online submission

- Thorough peer review

- No space constraints or color figure charges

- Immediate publication on acceptance

- Inclusion in PubMed, CAS, Scopus and Google Scholar

- Research which is freely available for redistribution 